\title{
SMART EDUCATORS FOR DIGITAL AGE STUDENTS
}

\author{
Nurul Fauziyyah \\ Nahdlatul Ulama Indonesia University
}

Abstrak: Tujuan dari penelitian ini adalah untuk meninjau pergeseran paradigma dari pendidik yang harus disesuaikan dengan perkembangan dan kebutuhan generasi saat ini atau dengan kata lain pendidik harus cerdas untuk siswa usia digital. Penelitian ini dilakukan oleh penelitian sebelumnya dan dikaitkan dengan fakta-fakta yang terjadi saat ini atau juga dikenal sebagai studi literatur. Metode analisis data yang digunakan dalam penelitian ini adalah metode analisis deskriptif. Hasil penelitian menunjukkan bahwa alasan utama untuk menggeser paradigma lama dalam sistem pendidikan bukan hanya tentang teknologi, tetapi cenderung pada kebutuhan 'lingkungan baru' dalam proses pembelajaran bagi siswa zaman digital. Memiliki keterampilan yang baik dalam teknologi adalah suatu keharusan, tetapi pendidik yang cerdas memiliki tantangan yang lebih besar untuk menafsirkan keterampilan itu untuk menciptakan proses pembelajaran yang menarik untuk menyerap hasil terbaik dari sistem pendidikan. Itu sebabnya pendidik harus mengubah paradigma lama dalam sistem pendidikan. Pendidik harus meningkatkan kreativitas mereka untuk menciptakan kelas yang menyenangkan untuk menarik perhatian siswa.

Kata kunci: pendidik cerdas, siswa usia digital, pendidikan, industri 4.0

Abstract: The purpose of this study was to review the shifting paradigm of educators that should be adjusted to the development and needs of the current generations or in other words educators must be smart to digital age students. This study was conducted by previous studies and associated with the facts that occur at this time or also known as a literature study. The data analysis method used in this study is descriptive analysis method. Results showed that the root reason to shift the old paradigm in education system is not just about technology, but it tends to the needs of 'new environment' in learning process for digital age students. Having good skill in technology is a must, but smart educators have greater challange to interprate that skill to create an interesting learning process to absorb the best result from the education system. That is why educators have to shift the old paradigm in education system. Educators have to improve their creativity to create an enjoyable class to attract students' attention.

Keywords: Smart educators, Digital age students, Education, Industry 4.0

\section{A. INTRODUCTION}

The era of rapid growing in technology and undeniable world of education must shift the "old paradigm" which still prioritizes text book learning to be more innovative or digital. Prensky (2001) stated that students in the present era are not the same as students in the previous era. They were born in the digital era and technology is an integral part of life. It is a natch that the approach to thinking and learning of students in 


\section{Nurul Fauziyyah}

the present era has changed extremely. There are not a few educators who are concerned about this, not a few who are indifferent and stick to the paradigm that students are the same in any era so that educators continue to carry out the educational process according to what they think is right, without wanting to keep up with the times and adjusting industry needs and the country will be the next generation. Even though the fact is that students in this digital age no longer like the old learning process, which can only dictate or can be called one-way teaching. The digital era is rampant and encourages us to be able to develop and adapt to what is called the industrial era 4.0, the digitalization era, an era where people called digital native are accustomed to fast access, transparency, ease of problem solving and many more.

In the world of education, the output that is born must be the generation that is able to adapt to it, even those who are able to grasp the world through what they learn. Demands are increasingly large and diverse for the world of education, especially educators. To be able to face the digitalization era, students must have at least problem solving, adaptability, collaboration, leadership, creativity and innovation so as to be able to produce a compatible generation that is able to fulfill and compete in the digital age, then the educator paradigm must change, it must shift into smart educators, educators who have innovations in presenting a more pleasant and appropriate learning climate for the times because what happened in the previous era cannot be used as a basis for educating students in this era. This is in accordance with what was stated by Wan Jusoh and Kamaruzaman (2009), If educators want to get the attention of students then make learning fun and a comfortable learning environment. Educators must follow the development of the times rather than protect and maintain based on what they got during the learning process first. Another opinion that also reinforces this is the statement of Jones, et.al. (2010) and Gaston (2006). Students who are digital natives are a generation that has and is accustomed to technology in their daily lives, but educators who are digital immigrants are one step behind it (Jones, et.al., 2010) can embrace students not by mastering the latest technology but with how to create a fun learning process for students.

By understanding and keeping abreast of the times and the application of learning methods, it will give birth to a superior generation that is superior, capable of competing in this industry 4.0 era. Educators must know how to attract students and attract attention in the learning process. In fact, understanding how students react to technology in learning, social and collaborative situations is very important to accommodate the learning needs of students with a more effective learning approach (Teo, 2013). Therefore, this study focuses more on the shifting paradigm of educators that should be adjusted to the development and needs of the current generations or in other words educators must be smart to digital age students.

\section{B. METHOD}

This study is a literature study conducted by previous studies and associated with the facts that occur at this time. Theoretical references obtained from literature study can be used as a reference or the main tool for research practice in the middle of the field. The types of data used in this study are primary data by conducting observations and secondary data obtained from the latest articles relating to the topics raised, books, other 
sources available on the internet. The data analysis method used in this study is descriptive analysis method. Descriptive analysis method is done by describing the facts obtained and then analyzed. Not only elaborate, but also provide the understanding and explanation needed.

\section{DIGITAL NATIVE}

The term of "Digital Natives" derives from a series of articles written since 2001 by the US technologist MarcPrensky. Prensky (2001) stated the generation of young people born since 1980 as digital natives due to what he perceived as an "origin" in using new technologies such as the internet, video games, mobile phone and all the other toys and tools of the digital age. Digital native and digital immigrant were initiated by Prensky. Digital native refers to the students nowadays who are the native speakers of the digital language of computers, video games and the Internet. Digital natives are characterized as: used to receiving fast information, like parallel process, multitasking, graphic first, random access, able to function best when networked, thrive on instant gratification and frequent rewards, prefer games to serious work, and twitch-speed.

Todays' generation are often called a digital or net generation because they were born in the information society and have a number of distinctive features that make them significantly different from previous generations instead of the education. The education system is changing in technical and technological aspects as well as in pedagogical such as new pedagogical approaches and paradigms compliant with learners' traits (Kiryakova, Gabriela, et.al. 2018). Todays' students are catagorized as native in digital era. They usually do almost everything in their life by technology. Their lifestyle are digitally habits. There are many other names, Herther (2009) that they are called, such as: iGeneration; Internet Generation; Generation I; Generation Z; First Digitals; MySpace Generation; Google Generation; Bebo Generation; Net Gen; Echo Boomers; Next Generation; Millennials; Digital Youth; and Born Digital.

\section{SHIFTING PARADIGM “DIGITAL IMMIGRANT" TO “DIGITAL NATIVE"}

Students are a digital era generation, a generation that is accustomed to do a lot of things with all digital or so-called "digital native". However, many educators are from the previous generation or what is called "digital immigrant". If the educator pretends not to notice the times or remains adamant about maintaining the old paradigm of learning methods and things like that, then the educator will not be able to embrace the students, will not be able to create an attractive learning climate for students, will not be able to give birth generations of people who have skills or skills that are needed in the current generation. Thus, educators should overlook the development of the times that occur and have innovations in creating learning processes that are fun and in accordance with the needs of students.

Movement to an age where the people's diversity is compounded by their generational differentiation is a must if we do not want to be disrupted in this era. These distinctions are part of the individual's structure, their framework, or who they are. Todays' people are really affected by their environment, background, and the attributes of their experiences. Whether it's because of their social, economical, heritage and 


\section{Nurul Fauziyyah}

educational experiences any or all of these are contributing factors in how they behave or approach new adventures (Autry and Berge, 2011).

Digital does not only affect environmental aspects or even to communicate, socialize, and entertain, but also fundamentally influences approaches in the world of education. Almost all aspects of life in the digital era are influenced by technology and even become a lifestyle. playing games, sending emails or using communication devices/mobile phones .Therefore, this generation is known as the digital generation.

One of the main problems faced by the current education system is educators who are digital immigrants, who speak in a pre-digital-age language and need great effort to be able to educate students who are digital natives, who speak languages. renewed. Students who are digital natives tend not to pay attention to ancient teaching methods, they are interested in new things that are increasingly developing in this digital era (Prensky, 2001).

\section{E. SMART EDUCATION}

Smart education is a concept that illustrates learning in the digital world that is designed and adapted to the needs of the digital generation. Smart technology and devices are the basis of smart education. They provide the ability to adapt and personalize learning and provoke students' commitment, motivation and activity. The main objective of the integration of technology and smart devices is to create an intelligent environment where learning is consistent with the needs and characteristics of digital learners. If educatos want to be loved by students, the educators have to be smart educators by adapting the keys of smart education. The solution to these problems is not only in the technology, but in the willingness and ability of educators to continue to learn and innovate to produce a learning climate that is suitable for the needs of the current generation of learners and in accordance with the times. In line with smart education which is a concept of depicting learning in the digital world that is designed and adapted to the needs of the digital generation. Smart technology and devices are the basis of smart education (Fauziyyah, N., 2019).

\section{F. FINDINGS AND DISCUSSIONS}

Hybrid progress in technology development requires higher qualifications to survive in this era, not only in industry or company, but also in education. Todays' students in all levels represent the first generation to grow up with the internet and other "new technologies" (Prensky, 2001). This generation is in indusrty 4.0 that is everything rely on technology. The definition of Industry 4.0 made by McKinsey as the next phase in the digitization of the manufacturing sector, driven by four disruptions: the astonishing rise in data volumes, computational power, and connectivity, especially new low-power wide-area networks; the emergence of analytics and business-intelligence capabilities; new forms of human-machine interaction such as touch interfaces and augmented-reality systems; and improvements in transferring digital instructions to the physical world, such as advanced robotics and 3-D printing. 
Todays' generation has been referred to as the " $\mathrm{N}$ Gen" for net generation or "D Gen" for digital generation. But one of the more descriptive words associated with this generation is "digital natives." These students have a language of their own when it comes to performing task or collaborating on digital technologies such as computers, cell phones, and video games. These technologies are common instruments that this generation is routinely exposed to during their daily lives. They have grown up being socialized and living a life differently than their parents. The digital landscape of today is full of instant messaging (IMing), e-mails, digital phones and video games. Not only do many of these technologies allow individuals to communicate rapidly but enables them access to additional informational resources from virtually any location by pushing a button. This technological environment is not the same world their parents' generation grew up experiencing.

The education system must respond to the stage of society's development and be in line with its needs and characteristics to prepare adolescents to be fully integrated members of community. In the modern information era, everything relys on technology, thus in education. Education becomes more engaging and interesting for students and provokes them to participate actively in the learning process. As a result, the quality and efficiency of training is improved. The undeniable fact is that the new generation, no matter whether it belongs to the group of digital learners or not, cannot be trained in the traditional ways. Teachers should adapt pedagogical approaches and implement new tools and technologies in the learning process in order to keep the relationship and communication between them and learners. Digital learners impose new requirements and have different expectations about the training. The role of educators is to create an authentic environment, using available innovative technologies that learners perceive as their own natural background. Modern society builds a digital world that aims to become a smart world. Society imposes new requirements on the education of adolescents so that they can fully integrate into it. The role of contemporary education is to equip learners with knowledge and skills as well as to prepare them to work with technologies inherent in digital era. An attractive, interesting and fun learning environment is needed, in order to keep students' attention on what happens in class, provide them with interactive, exciting and unforgettable experience and opportunities for active participation (Kiryakova, Gabriela, et.al., 2018).

This is in line with Marchetta, James et.al. (2018) on his research stated that the digital "native" generation as learners demonstrate different learning behaviors, by exploring relationships between technology use and productive learning habits, and with Wan Jusoh and Ahmad (2016) that stated on the results of his research that the majority of students stated that iMindMap which is one of the innovations in learning is more interesting compared to conventional teaching methods and found that iMindMap was able to explain the points of associated learning and related to each other.

Being smart educators is one way to get involve with digital age students. Educators have to be more concern with the needs of digital age students. It will not work if educators still stand to their old paradigm in education system because in industry 4.0, everything tends to be digitally solved and it creates a meeting of generations (digital immigrant and digital native), in theory, significantly different, so it 


\section{Nurul Fauziyyah}

is necessary to identify appropriate educational forms according to the situation at hand: a new culture of learning .

Todays' learners or students in this era need something new in education system. Their characters affected by their lifestyle and environment that rely on technology. Beside that, digital era students also needs fun-interactive learning process. Educators have to make a colorful and joy class in order to catch students intention. Chaves, et.al. (2016) said that the attitudes of students in regard to learning seems to be influenced more by the teaching methods used by teachers. The educational approach should show committed to the conservation of culture, but also equally with the advancement of knowledge, the professional training and the social justice. Thus, smart educators should use technology or common-games as mediator in learning process.

The adaptation of the environment is based on an analysis of learners' behavior and performance, as well as the context of the online and real situation (Hwang, G. J., 2014). The fundamental reason to shift the old paradigm in education system is not just about technology, but it tends to the needs of 'new environment' in learning process for digital age students. Having good skill in technology is a must, but smart educators have greater challange to interprate that skill to create an interesting learning process to absorb the best result from the education system. That is in line with Kiryakova, Gabriela, et.al. (2018) who stated that the shifts in the field of education are not the new technologies, but the new learners with their new needs and requirements. Technologies are a means that allows the necessary learning environment to be created where the learning process can be realized in the most effective way.

High requirement for smart educators to master in technology is just one of ways not to be distrupted in this era. The most important one is smart educators have to be creative and innovative in developing learning methods for digital age students, so education system as a whole could be more interesting for them. Marchetta, James et.al. (2018) stated in her paper about what teachers and educators can do to raise the willingness of digital natives to learn and to push their boundaries. By using technology for innovation, educators should not assume that digital natives are efficient researchers, they also have to balance between activity-based learning and distractions, and Incorporate Social Media and update frequently.

Fun learning process created by smart environment that addapt individual needs of digital age students to get along with the industy 4.0. Providing the necessary learning tools, suggestions or help tips to the learners at the right time and place, are some of ways to fulfil their needs (Crook, C., 2016, Zhu, Z. T., et.al., 2016). Smart educators should give extra effort on creating fun learning, albeit with minor uses of tools delivering content, as educators we need to always be innovative and creative in delivering knowledge to achieve the optimum learning outcome.

\section{G. CONCLUSIONS}

As we all know that this generation is in indusrty 4.0 that is everything rely on technology so the education system must respond to the stage of society's development and be in line with its needs and characteristics to prepare adolescents to be fully integrated members of community. Educators must shift the old paradigm of learning 
methods to follow the times and the development of students in this era. It takes the open-minded, innovative, active, and creative nature. The quality and efficiency of training is improved. The undeniable fact is that the new generation, no matter whether it belongs to the group of digital learners or not, cannot be trained in the traditional ways. Digital age students need innovation in education system especially the ability of educators to innovate learning process. These are in line with Chaves, et.al. (2016) and Kennedy, et.al. (2008).

The root reason to shift the old paradigm in education system is not just about technology, but it tends to the needs of 'new environment' in learning process for digital age students. Having good skill in technology is a must, but smart educators have greater challange to interprate that skill to create an interesting learning process to absorb the best result from the education system. Smart educators should use technology or everything that relate to digital age students as a mean of learning process, such as games, movie, or so on. Thus, smart educators have to present an unpredictable-joy learning process so the students will lose track of time because the class. That is why educators have to shift the old paradigm in education system. Educators have to improve their creativity to create an enjoyable class to attract students' attention.

\section{REFERENCES}

Autry, Alex J. and Zane Berge. 2011. "Digital natives and digital immigrants: getting to know each other". Industrial and Commercial Training, Vol. 43 No. 7, pp. 460466.

Chaves, et.al. 2016. "Education in times net generation: how digital immigrants can teach digital natives?". HOLOS, Year 32, Vol. 2.

Crook, C. 2016. "The discourse of a 'smart' technology: implications for educational practice”. International Journal of Smart Technology and Learning, 1(1), 4-20.

Fauziyyah, N. 2019." The potential of augmented reality to transform education into smart education: a review". Jurnal PAJAR (Pendidikan dan Pengajaran), 3(4), 966-973. DOI: http://dx.doi.org/10.33578/pjr.v3i4.7433.

Gaston, J. 2006. "Reaching and teaching the digital natives". Library HiTech News, Vol. 23 No.3, pp. 12-13.

Herther, N.K. (2009). Digital natives and immigrants, cover story. Online, Vol.33 No.6, p.14.

Hwang, G. J. 2014. "Definition, framework and research issues of smart learning environments- a context-aware ubiquitous learning perspective". Smart Learning Environments, 1(1), 4.

Jones, C., et.al. 2010. "Net generation or digital natives: is there a distinct new generation entering university?". Computers and Education, 54, 722-732. 


\section{Nurul Fauziyyah}

Kennedy, g., Judd, t., Churchward, a., Gray, k., Krause. 2008. "First year students' experiences with technology: are they digital natives?". Australasian Journal of Educational Technology, Vol. 24, p.108-122.

Kiryakova, Gabriela, et.al. 2018. "The Potential of augmented reality to transform education into smart education". TEM Journal, Vol. 7, Issue 3, Pages 556-565.

Marchetta, James, et.al. 2018. "Preferences and learning behaviors of digital natives". Northeast Business \& Economics Association Proceedings 2018.

Prenksy, M. 2001. "Digital natives, digital immigrants". On the Horizon, Vol.9 No.5, pp.1-6.

Teo, T. 2013. "An initial development and validation of a digital natives assessment scale (DNAS)”. Computers \& Education Journal, vol. 67, pp. 51-57, 2013.

Wan Jusoh and Ahmad. 2016. "iMindMap as an innovative tool in teaching and learning accounting: an exploratory study". Interactive Technology and Smart Education, Vol. 13 No. 1, pp. 71-82.

Zhu, Z. T., Yu, M. H., and Riezebos, P. 2016. "A research framework of smart education". Smart Learning Environments, 3(1). 